\title{
Review
}

\section{Residual platelet reactivity on aspirin therapy and recurrent cardiovascular events — A meta-analysis}

\author{
Francesco Sofi ${ }^{\mathrm{a}, \mathrm{b}, *}$, Rossella Marcucci ${ }^{\mathrm{a}, \mathrm{b}}$, Anna Maria Gori ${ }^{\mathrm{a}, \mathrm{b}}$, \\ Rosanna Abbate $^{\mathrm{a}, \mathrm{b}}$, Gian Franco Gensini ${ }^{\mathrm{a}, \mathrm{b}, \mathrm{c}}$ \\ ${ }^{a}$ Department of Medical and Surgical Critical Care, Thrombosis Centre, University of Florence, Azienda Ospedaliero-Universitaria Careggi, Florence, Italy \\ ${ }^{\mathrm{b}}$ Center for the Study at Molecular and Clinical Level of Chronic, Degenerative and Neoplastic Diseases to Develop Novel Therapies, \\ University of Florence, Italy \\ ${ }^{\mathrm{c}}$ Don Carlo Gnocchi Foundation, IRCCS, Florence, Italy
}

Received 24 August 2007; received in revised form 4 December 2007; accepted 11 December 2007

Available online 1 February 2008

\begin{abstract}
Background: Recently, a growing body of evidence on the possible role of residual platelet reactivity (RPR) in affecting clinical events has accumulated. The aim of this study was to systematically assess the relationship between RPR on acetylic salicylic acid (ASA) therapy and the occurrence of recurrent events in a meta-analysis of prospective studies.

Methods: A systematic literature search of MEDLINE, EMBASE, Science Citation Index, the Cochrane Systematic Review Database and bibliographies of retrieved articles through May 2007 was conducted. Studies were included if they analysed RPR in coronary heart disease patients in relation to the occurrence of adverse coronary events during follow-up.

Results: Eleven prospective studies, incorporating 1952 patients with coronary heart disease followed for a time ranging from 6 days to 4 years, met the inclusion criteria. The pooled analysis demonstrated a significantly increased relative risk of adverse clinical events during follow-up for patients with RPR on ASA therapy (RR: $3.11,95 \% \mathrm{CI} 1.88-5.15 ; p<0.0001)$. Moreover, the association between RPR and cardiovascular recurrences remained to be statistically significant even when subgroup analyses performed according to the duration of follow-up, ASA dosage, characteristics of the study population, and laboratory method were conducted.

Conclusions: The present meta-analysis documents a significant association between RPR on ASA treatment and recurrent cardiovascular events. More prospective studies are needed to determine the independent prognostic importance of RPR during aspirin therapy and possible benefit of individually tailored anti-platelet treatment strategies in these patients.
\end{abstract}

(C) 2007 Elsevier Ireland Ltd. All rights reserved.

Keywords: Aspirin; Antiplatelet therapy; Residual platelet reactivity; Recurrence; Meta-analysis

\section{Introduction}

Antiplatelet drugs have an established place in the secondary prevention of a variety of vascular events, such as fatal and non-fatal coronary heart disease (CHD), stroke and pe-

\footnotetext{
* Corresponding author. Department of Medical and Surgical Critical Care, Thrombosis Centre, University of Florence, Azienda OspedalieroUniversitaria Careggi, Viale Morgagni 85, 50134 Florence, Italy, Tel.: +39 055 7949420; fax: +39055 7949418 .

E-mail address: francescosofi@gmail.com (F. Sofi).
}

ripheral arterial disease [1]. Indeed, results from the metaanalysis of the "Antiplatelet Trialists' Collaboration" demonstrated that acetyl salicylic acid (ASA) therapy is able to reduce the risk of non-fatal myocardial infarction by $35 \%$ and the risk of total vascular events by $18 \%$ in patients with manifest coronary heart and cerebrovascular disease [1].

However, in a consistent proportion of vascular patients on ASA therapy residual platelet reactivity (RPR), the so-called aspirin resistance, is detectable [2]. A systematic review that recently assessed the prevalence of RPR in patients with CHD on ASA therapy reported an overall prevalence of $25 \%$ among 
all the published studies [3]. The question whether this phenomenon has a significant clinical implication on the occurrence of atherothrombotic events has not been, to date, definitely answered. Some studies evaluating the occurrence of clinical events during follow-up in patients with RPR have been conducted [4-6], and a recent meta-analysis by Snoep et al., evidenced an association between a laboratory-defined aspirin resistance and a higher risk of recurrent cardiovascular events [7]. The aim of this study is to systematically review all the available studies that prospectively investigated the possible association between RPR on ASA therapy and the occurrence of major adverse cardiovascular events in patients with CHD.

\section{Methods}

\subsection{Search strategy}

An extensive systematic literature search in order to identify studies evaluating the association between RPR and the occurrence of secondary cardiovascular events was conducted. The search was performed by using a combined text word and MeSH search strategy of the terms "acetyl salicylic acid", "aspirin", "antiplatelet", "residual platelet reactivity", and "persistent platelet reactivity" in combination with "resistance", "failure", "recurrence" and "major adverse cardiovascular events", "cardiovascular disease", "coronary artery disease", "coronary heart disease", "ischemic heart disease", "myocardial infarction", and "acute coronary syndromes" through the electronic databases MEDLINE (from 1966 to May 2007), EMBASE (from 1974 to May 2007), Science Citation Index (from 1994 to May 2007), and the Cochrane Systematic Review databases. Furthermore, a manual search of citations from relevant original studies and review articles was performed.

\subsection{Study eligibility}

To be included in the analysis, studies had to fulfil the following criteria:

- Prospective study design

- CHD patients

- Patients on ASA therapy for secondary prevention of cardiovascular events

- Clear definition of RPR

- Clear definition of laboratory methods used to identify RPR

- Relative risk, hazard ratio, or odds ratio and their corresponding $95 \%$ confidence intervals (or data to calculate them)

\subsection{Study selection and data collection}

All data were independently extracted by 2 investigators (F.S., and R.M.) through the use of a standardized data extraction tool and entered into separate databases. Results were compared, and disagreements were resolved by discussion with a third investigator (A.M.G.). The interobserver agreement for the study selection was 0.90 . Relevant data included the first author's name, year of publication, country of origin of the centres, number of participants and number of patients with RPR, ASA dosage, duration of follow-up, participants' age, gender of participants, number of patients with clinical recurrences at follow-up, laboratory method used to measure RPR, definition of RPR, relative risks or hazard ratios of $\mathrm{CHD}$ and corresponding $95 \% \mathrm{CI}$, and covariates adjusted in the statistical analysis.

\subsection{Statistical analyses}

Data were analyzed by using Review Manager (RevMan) software for Windows (version 4.2) by the Cochrane Collaboration, 2003 and Statistical Package for Social Sciences (SPSS) software for Windows (version 13.0). The K statistic was used to assess agreement between reviewers for study selection. The results of each study were reported as relative risk (RR), hazard ratio, or dichotomous frequency data. Hazard ratios were treated as RRs, whereas frequency data were algebraically converted into RRs. When available, we used the results of the original studies from multivariable models with the most complete adjustment for potential confounders; the confounding variables included in this analysis are shown in Table 1. We used a random-effects model which accounts for interstudy variation and provides a more conservative effect than the fixed model. Thus, we calculated random-summary RR with $95 \%$ confidence intervals (CI), by using inversevariance method. The potential sources of heterogeneity were assessed by using the Cochran's $Q$ test to assess between-study differences and the $I^{2}$ statistic to quantify the proportion of inconsistency across the study results. Publication bias was assessed using a funnel plot of effect size against standard error.

\section{Results}

\subsection{Search results}

The search strategy generated 26 potentially relevant studies. Eight studies were eliminated because they were not prospective studies, 4 because they reported only clopidogrel resistance, 2 because they did not evaluate clinical cardiovascular recurrences during the follow-up but only surrogate markers, and 1 because only a meeting abstract was available. As a result, a total of 11 prospective studies were included in the meta-analysis [8-18].

\subsection{Studies' characteristics}

Characteristics of the included studies are presented in Table 1.

The included studies comprehended a total of 1952 patients with CHD followed for a time ranging from 6 days to 4 years, with study sample sizes ranging from 71 to 326 
Table 1

Characteristics of the studies included in the meta-analysis

\begin{tabular}{|c|c|c|c|c|c|c|c|c|c|c|}
\hline $\begin{array}{l}\text { Study author, year } \\
\text { (country) }\end{array}$ & $\begin{array}{l}\text { Patients } \\
\text { with } \\
\text { residual } \\
\text { platelet } \\
\text { activity/ } \\
\text { patients }\end{array}$ & $\begin{array}{l}\text { Type of } \\
\text { patients }\end{array}$ & $\begin{array}{l}\text { Aspirin } \\
\text { dosage }\end{array}$ & Follow-up & Age & $\begin{array}{l}\text { Males/ } \\
\text { females }\end{array}$ & $\begin{array}{l}\text { Clinical } \\
\text { recurrences, } \\
\mathrm{n}\end{array}$ & $\begin{array}{l}\text { Laboratory } \\
\text { method }\end{array}$ & $\begin{array}{l}\text { Definition of } \\
\text { residual } \\
\text { platelet } \\
\text { reactivity }\end{array}$ & $\begin{array}{l}\text { Adjustment } \\
\text { factors }\end{array}$ \\
\hline $\begin{array}{l}\text { Gum et al., } \\
2003 \\
\text { [8] (U.S.A.) }\end{array}$ & $17 / 326$ & $\begin{array}{l}\text { Stable } \\
\text { CHD }\end{array}$ & $\begin{array}{l}325 \\
\mathrm{mg} / \mathrm{die}\end{array}$ & 679 days & 60 & $253 / 73$ & 34 & $\begin{array}{l}\text { Platelet } \\
\text { aggregation } \\
(10 \mu \mathrm{M} \mathrm{ADP} \\
\text { and } 0.5 \mathrm{mg} / \\
\mathrm{mL} \mathrm{AA})\end{array}$ & $\begin{array}{l}\text { Aggregation } \\
\geq 70 \% \text { with } \\
10 \mu \mathrm{M} \text { ADP } \\
\text { and } \geq 20 \% \\
\text { with } 0.5 \mathrm{mg} / \\
\text { mL AA }\end{array}$ & $\begin{array}{l}\text { Age, gender, race, smoking } \\
\text { habit, diabetes, hypertension, } \\
\text { dyslipidemia, } \\
\text { revascularization, } \\
\text { myocardial infarction, } \\
\text { haemoglobin, platelet count, } \\
\text { creatinine, aspirin sensitivity }\end{array}$ \\
\hline $\begin{array}{l}\text { Andersen } \\
\text { et al., } 2003 \\
\text { [9] (Norway) }\end{array}$ & $25 / 71$ & AMI & $\begin{array}{l}160 \\
\mathrm{mg} / \mathrm{die}\end{array}$ & 4 years & 71 & $56 / 15$ & 20 & PFA-100 & $\begin{array}{l}\text { Closure time } \\
\text { EPI } \leq 196 \mathrm{~s}\end{array}$ & None \\
\hline $\begin{array}{l}\text { Marcucci et al., } \\
2006[10] \\
\text { (Italy) }\end{array}$ & $41 / 146$ & AMI & $\begin{array}{l}100 \\
\mathrm{mg} / \mathrm{die}\end{array}$ & 1 year & 65 & $115 / 31$ & 44 & PFA-100 & $\begin{array}{l}\text { Closure time } \\
\text { EPI }<203 \text { s }\end{array}$ & $\begin{array}{l}\text { Age, gender, diabetes, no. } \\
\text { of stenosed coronary } \\
\text { arteries, left ventricular } \\
\text { ejection } \\
\text { fraction }\end{array}$ \\
\hline $\begin{array}{l}\text { Gianetti et al., } \\
2006[11] \\
\text { (Italy) }\end{array}$ & $76 / 175$ & $\begin{array}{l}\text { ACS } \\
\text { and } \\
\text { stable } \\
\text { angina }\end{array}$ & $\begin{array}{l}\text { Not } \\
\text { reported }\end{array}$ & 6 months & $\begin{array}{l}\text { Not } \\
\text { reported }\end{array}$ & $108 / 67$ & 6 & PFA-100 & $\begin{array}{l}\text { Closure time } \\
\text { EPI }<190 \mathrm{~s}\end{array}$ & $\begin{array}{l}\text { Age, diabetes, smoking } \\
\text { habit, hypertension, LDL- } \\
\text { cholesterol }\end{array}$ \\
\hline $\begin{array}{l}\text { Fuchs et al., } \\
2006[12] \\
\text { (Austria) }\end{array}$ & $\begin{array}{l}\text { Not } \\
\text { reported/ } \\
208\end{array}$ & ACS & $\begin{array}{l}\text { Not } \\
\text { reported }\end{array}$ & 28 months & $\sim 60$ & $175 / 33$ & 58 & PFA-100 & $\begin{array}{l}\text { Closure time } \\
\text { EPI }<300 \mathrm{~s}\end{array}$ & $\begin{array}{l}\text { Diabetes, von Willebrand } \\
\text { factor, beta-blockers, } \\
\text { clopidogrel }\end{array}$ \\
\hline $\begin{array}{l}\text { Stejskal et al., } \\
2006[13] \\
\text { (Czech } \\
\text { Republic) }\end{array}$ & $46 / 103$ & ACS & $\begin{array}{l}100 \\
\mathrm{mg} / \mathrm{die}\end{array}$ & 4 years & 64 & $66 / 37$ & 79 & $\begin{array}{l}\text { Spontaneous } \\
\text { and after } \\
\text { induction of } \\
\text { cationic } \\
\text { propyl } \\
\text { gallate- } \\
\text { platelet } \\
\text { aggregation }\end{array}$ & $\begin{array}{l}\text { Spontaneous } \\
\text { aggregation } \\
>5 \% \\
\text { Slope of the } \\
\text { aggregation } \\
\text { curve after } \\
\text { induction } \\
>53 \% / \mathrm{min}\end{array}$ & None \\
\hline $\begin{array}{l}\text { Pamukcu et al., } \\
2006[14] \\
\text { (Turkey) }\end{array}$ & $20 / 195$ & ACS & $\begin{array}{l}100-300 \\
\mathrm{mg} / \mathrm{die}\end{array}$ & 1 year & $18-80$ & $172 / 23$ & 19 & PFA-100 & $\begin{array}{l}\text { Closure time } \\
<186 \mathrm{~s}\end{array}$ & Not reported \\
\hline $\begin{array}{l}\text { Cuisset et al., } 2006 \\
\text { [15] (France) }\end{array}$ & $26 / 106$ & ACS & $\begin{array}{l}160 \\
\mathrm{mg} / \mathrm{die}\end{array}$ & 1 month & 64.2 & $82 / 24$ & 12 & $\begin{array}{l}\text { Platelet } \\
\text { aggregation } \\
(0.5 \mathrm{mg} / \\
\mathrm{mL} \mathrm{AA})\end{array}$ & $\begin{array}{l}\text { Upper } \\
\text { quartile of } \\
\text { AA-induced } \\
\text { platelet } \\
\text { aggregation }\end{array}$ & $\begin{array}{l}\text { Age, gender, traditional } \\
\text { cardiovascular risk factors, } \\
\text { treatment, c-reactive protein, } \\
\text { P-selectin }\end{array}$ \\
\hline $\begin{array}{l}\text { Malek et al., } 2007 \\
{[16] \text { (Poland) }}\end{array}$ & $9 / 91$ & ACS & $\begin{array}{l}75 \\
\mathrm{mg} / \mathrm{die}\end{array}$ & 6 days & $\sim 60$ & $62 / 29$ & 11 & PFA-100 & $\begin{array}{l}\text { Closure time } \\
\text { EPI }<190 \mathrm{~s}\end{array}$ & None \\
\hline $\begin{array}{l}\text { Pamukcu et al., } \\
2007 \text { [17] } \\
\text { (Turkey) }\end{array}$ & $52 / 234$ & $\begin{array}{l}\text { Stable } \\
\text { CHD }\end{array}$ & $\begin{array}{l}100-300 \\
\mathrm{mg} / \mathrm{die}\end{array}$ & $\begin{array}{l}20.6 \\
\text { months }\end{array}$ & 57 & $182 / 52$ & 28 & PFA-100 & $\begin{array}{l}\text { Closure time } \\
\text { EPI }<186 \mathrm{~s}\end{array}$ & None \\
\hline $\begin{array}{l}\text { Poulsen et al. } 2007 \\
\text { [18] (Denmark) }\end{array}$ & $70 / 297$ & AMI & $\begin{array}{l}150 \\
\mathrm{mg} / \mathrm{die}\end{array}$ & 1 year & $\sim 70$ & $239 / 59$ & 49 & PFA-100 & $\begin{array}{l}\text { Closure time } \\
\text { EPI }<165 \mathrm{~s}\end{array}$ & None \\
\hline
\end{tabular}

Data are for patients included in analyses of recurrent cardiovascular events, and may differ from the characteristics of the total study populations.

$\mathrm{CHD}=$ Coronary Heart Disease; $\mathrm{ADP}=$ Adenosine DiPhosphate; $\mathrm{AA}=$ Arachidonic Acid; $\mathrm{AMI}=$ Acute Myocardial Infarction; PFA $=$ Platelet Function Analyzer; EPI = Epinephrine; ACS = Acute Coronary Syndromes.

patients. There were 3 studies involving patients with stable cardiovascular disease whereas the remaining studies included patients with acute coronary syndromes who underwent primary percutaneous intervention. With regard to the laboratory method used for identifying patients with RPR, most of the included studies $(n=8)$ used the PFA-100 system. As regarding statistical analysis, in addition, 6 out of
11 studies reported statistical data not adjusted for potential confounders.

\subsection{Meta-analyses}

The cumulative analysis for patients with RPR on ASA therapy showed a significant increased risk of cardiovascular 


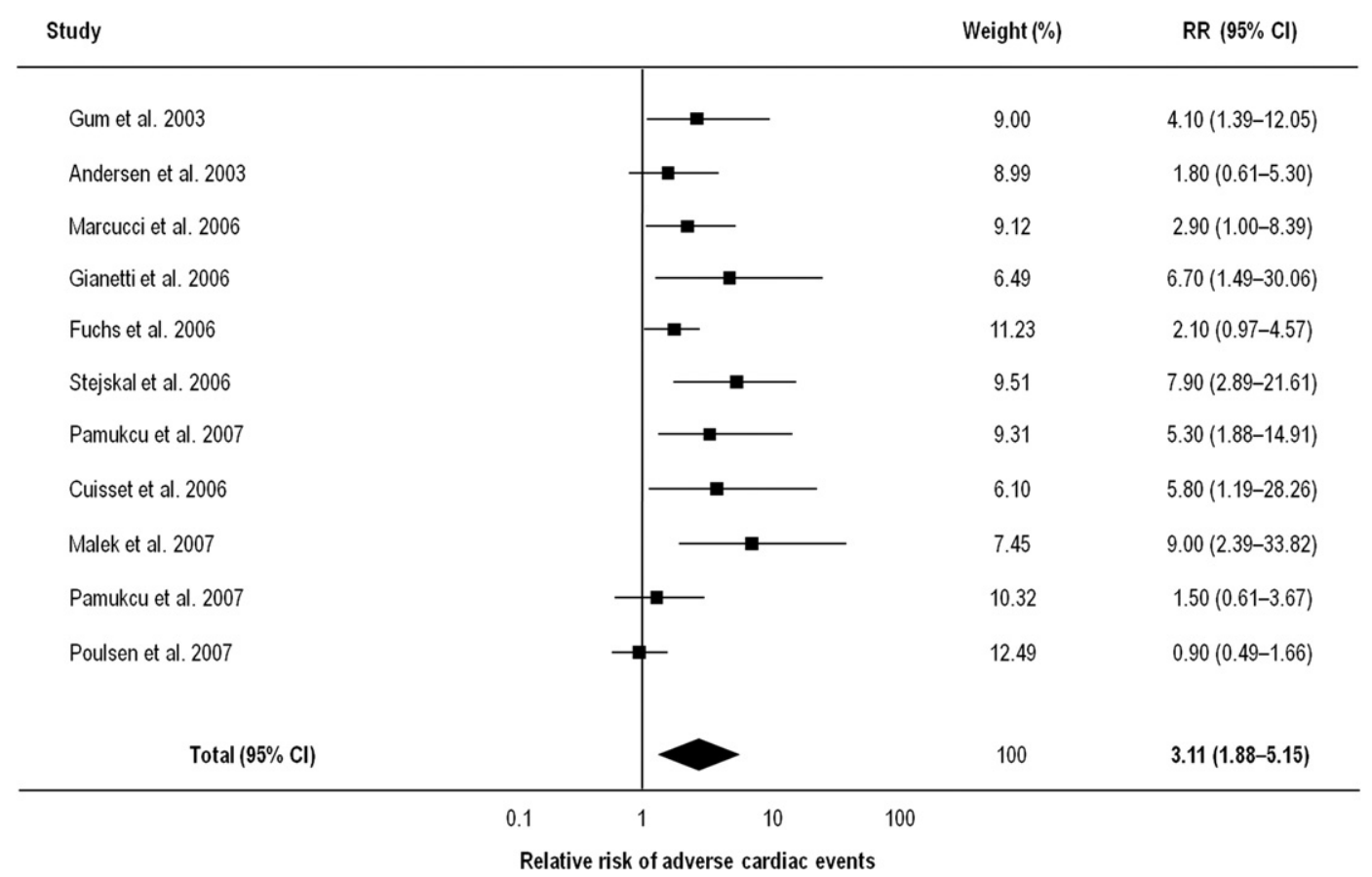

Fig. 1. RR and 95\% CI for recurrent cardiovascular events in patients with residual platelet reactivity on acetyl salicylic acid therapy. Studies are listed in chronological order by year of publication. Reference for each article is presented as number in parentheses. Results are for available analyses of recurrent cardiovascular events, and may differ from the results of the total study populations. Boxes represent the relative risk (RR), and lines represent the 95\% confidence interval (CI) for studies. The diamond represents the pooled RR, and its width represents its $95 \%$ CI.

recurrences during follow-up (RR: 3.11, 95\%CI 1.88-5.15; $p<0.00001$ ) (Fig. 1). However, a significant heterogeneity across studies was reported $\left(I_{2}: 62.7 \% ; p=0.003\right)$. The study by Poulsen et al. [18] resulted to significantly influence the heterogeneity of the analysis; after exclusion of this study the association was confirmed (RR: 3.56, 95\%CI 2.36-5.36; $p<0.0001)$ and no significant heterogeneity was reported $\left(I_{2}\right.$ : $30.3 \% ; p=0.17)$. The funnel plot of effect size against standard error was broadly symmetric, so consistent with the conclusion that there was no publication bias. In addition, the association remained statistically significant even after exclusion of studies that reported only crude unadjusted data $(n=5)$ (RR: $3.19,95 \%$ CI 1.97-5.19, $p<0.00001)\left(I_{2}: 0 \%\right.$; test of homogeneity $p=0.59$ ).

\subsection{Sensitivity analyses}

To further examine the association between RPR and occurrence of cardiovascular recurrences we performed subgroup analyses, by selecting studies according to some specific variables. Accordingly, an increased risk of clinical recurrences was observed when studies were subgrouped according to the duration of follow-up $[\geq 1$ year, studies $n=8$; RR: 2.51 (95\%CI 1.46-4.32), $p=0.0009 ;<1$ year, studies $n=3$; RR: 7.25 (95\%CI 3.12-16.81), $p<0.00001$ ], ASA dosage $[\leq 100 \mathrm{mg}$, studies $n=3$; RR: $5.69(95 \% \mathrm{CI}$ 2.81-11.54), $p<0.00001$; > $100 \mathrm{mg}$, studies $n=6$; RR: 2.45 (95\%CI 1.45-4.19), $p=0.002]$, patients' characteristics [acute coronary syndromes, studies $n=8$; RR: 3.17 (95\%CI
1.68-6.00), $p=0.0001$; stable CHD, studies $n=3$; RR: 3.02 (95\%CI 1.26-7.26), $p<0.0001]$, and method used for determining RPR [PFA-100, studies $n=8$; RR: $2.52(95 \%$ CI 1.44-4.41), $p=0.001$; platelet aggregation, studies $n=3$; RR: 5.82 (95\%CI 2.99-11.34), $p<0.0001]$.

\section{Discussion}

The present meta-analysis conducted in 11 prospective studies, with an overall population of 1952 CHD patients followed for a time ranging from 6 days to 4 years, showed a significant increased risk of clinical recurrences for patients who manifested RPR on ASA treatment. This association remained statistically significant even when subgroup analyses according to the duration of follow-up, ASA dosage, patients' characteristics, and laboratory method were performed.

ASA is currently the most effective therapeutic option for secondary prevention of fatal and non fatal cardiovascular events in patients with cardiovascular disease. Its clinical effectiveness for patients suffering from various vascular diseases has been well established in many clinical trials and in meta-analyses [1]. However, in a proportion of patients with cardiovascular disease under ASA treatment, RPR, the socalled aspirin resistance, is detectable [2]. Estimates of the prevalence of RPR in clinical trials vary enormously, ranging from $0 \%$ to over than $50 \%$ [4-6]. In a recent systematic review of all the clinical trials that evaluated persistent platelet reactivity in patients under ASA therapy, the mean prevalence of RPR was nearly $25 \%$ [3]. Some clinical prospective studies 
reported a significant association between RPR and the occurrence of secondary cardiovascular events [4-6], and a recent meta-analysis by Snoep et al. [7] reported a significant role for the laboratory-defined aspirin resistance on the risk of clinical cardiovascular recurrences.

In the present meta-analysis we confirm the data recently published by Snoep et al. [7], by systematically analysing all the published clinical studies that evaluated platelet function among patients with CHD on ASA therapy. This in order to give further insights on this matter that is arousing increasing clinical interest among physicians and researchers. The main result of our study is that CHD patients with a laboratory evidence of RPR on ASA therapy were at an increased risk of clinical recurrences. This datum, though not conclusive, gives strong stimulus to researchers to continue working in this field.

To date, the mechanism of RPR on ASA therapy is still uncertain. Some investigators reported a nonadherence to therapy as the main cause of persistent platelet activation, by hypothesising this phenomenon only as "non-compliance" [19]. Others, instead, hypothesised that the interaction of platelets with other cells, as well as the presence of polymorphisms in genes encoding for proteins involved in the platelet function may help to explain the pathophysiological basis for RPR in these patients [20-24]. Additionally, diabetes, duration of ASA therapy and dosage have been also demonstrated to likely contribute in determining RPR [25].

Our meta-analysis suffers from some limitations that strictly derive from the studies included in the final analysis. Actually, a number of laboratory methods for the measurement of RPR have been used, and there is not an accepted uniform measure for screening platelet function in the clinical setting. Furthermore, the studies differ substantially for several features such as clinical setting of patients enrolled, ASA dosage, duration of treatment, laboratory method, and definition of RPR, so determining a statistically significance for the heterogeneity test of the cumulative analysis. However, after exclusion of the study by Poulsen et al. [18], which was not designed to investigate the prognostic role of residual platelet reactivity on the occurrence of atherothrombotic events, the heterogeneity test lost its significance. Finally, adherence to ASA therapy has not been systematically assessed, and most of the included studies lack of adjustment for confounding factors in the multivariable statistical models. However, subgroup analyses conducted according to some specific variables, i.e. laboratory method, duration of ASA treatment and ASA dosage confirmed the significant association observed between such phenomenon and the occurrence of secondary clinical events, so being in line with the results of our previous study documenting a concordance between different methods used for the measurement of RPR on ASA [26].

In conclusion, the present meta-analysis conducted in 11 prospective studies and including over than 1900 patients with CHD demonstrated that RPR is significantly associated with an increased risk of recurrent cardiovascular events, by possibly suggesting a clinical implication of RPR, though in apparent contrast with the indications of the scientific associations [27]. However, more prospective studies are needed to determine the independent prognostic importance of RPR during aspirin therapy and the possible benefit of individually tailored anti-platelet treatment strategies in these patients.

\section{References}

[1] Antithrombotic Trialists' Collaboration. Collaborative meta-analysis of randomised trials of antiplatelet therapy for prevention of death, myocardial infarction, and stroke in high risk patients. BMJ 2002;324:71-86.

[2] Gum PA, Kottke-Marchant K, Poggio ED, et al. Profile and prevalence of aspirin resistance in patients with cardiovascular disease. Am J Cardiol 2001;88:230-5.

[3] Hovens MMC, Snoep JD, Eikelboom JCJ, van der Bom JG, Mertens BJA, Huisman MV. Prevalence of persistent platelet reactivity despite use of aspirin: a systematic review. Am Heart J 2007;153:175-81.

[4] Grotemeyer KH, Scharafinski HW, Husstedt IW. Two-year follow-up of aspirin responder and aspirin non responder. A pilot-study including 180 post-stroke patients. Thromb Res 1993;71:397-403.

[5] Helgason CM, Bolin KM, Hoff JA, et al. Development of aspirin resistance in persons with previous ischemic stroke. Stroke 1994;25:2331-6.

[6] Eikelboom JW, Hirsh J, Weitz JI, Johnston M, Yi Q, Yusuf S. Aspirinresistant thromboxane biosynthesis and the risk of myocardial infarction, stroke, or cardiovascular death in patients at high risk for cardiovascular events. Circulation 2002;105:1650-5.

[7] Snoep JD, Hovens MMC, Eikenboom JCJ, van der Bom JG, Huisman MV. Association of laboratory-defined aspirin resistance with a higher risk of recurrent cardiovascular events. A systematic review and metaanalysis. Arch Intern Med 2007;167:1593-9.

[8] Gum PA, Kottke-Marchant K, Welsh PA, White J, Topol EJ. A prospective, blinded determination of the natural history of aspirin resistance among stable patients with cardiovascular disease. J Am Coll Cardiol 2003;41:961-5

[9] Andersen K, Hurlen M, Amesen H, Seljeflot I. Aspirin nonresponsiveness as measured by PFA-100 in patients with coronary artery disease. Thromb Res 2003;108:37-42.

[10] Marcucci R, Paniccia R, Antonucci E, et al. Usefulness of aspirin resistance after percutaneous coronary intervention for acute myocardial infarction in predicting one-year major adverse coronary events. Am J Cardiol 2006;98:1156-9.

[11] Gianetti J, Parri MS, Sbrana S, et al. Platelet activation predicts recurrent ischemic events after percutaneous coronary angioplasty: a 6 months prospective study. Thromb Res 2006;118:487-93.

[12] Fuchs I, Frossard M, Spiel A, Riedmuller E, Laggner AN, Jilma B. Platelet function in patients with acute coronary syndrome (ACS) predicts recurrent ACS. J Thromb Haemost 2006;4:2547-52.

[13] Stejskal D, Vaclavik J, Lacnak B, Proskova J. Aspirin resistance measured by cationic propyl gallate platelet aggregometry and recurrent cardiovascular events during 4 years of follow-up. Eur J Intern Med 2006;17:349-54.

[14] Pamukcu B, Oflaz H, Oncul A, et al. The role of aspirin resistance on outcome in patients with acute coronary syndrome and the effect of clopidogrel therapy in the prevention of major cardiovascular events. J Thromb Thrombolysis 2006;22:103-10.

[15] Cuisset T, Frere C, Quilici J, et al. High post-treatment platelet reactivity identified low-responders to dual antiplatelet therapy at increased risk of recurrent cardiovascular events after stenting for acute coronary syndrome. J Thromb Haemost 2006;4:542-9.

[16] Malek LA, Spiewak M, Filipiak KJ, et al. Persistent platelet activation is related to very early cardiovascular events in patients with acute coronary syndromes. Kardiol Pol 2007;65:40-5. 
[17] Pamukcu B, Oflaz H, Onur I, et al. Clinical relevance of aspirin resistance in patients with stable coronary artery disease: a prospective follow-up study (PROSPECTAR). Blood Coagul Fibrinolysis 2007;18:187-92.

[18] Poulsen TS, Kristensen RS, Korsholm L, et al. Variation and importance of aspirin resistance in patients with cardiovascular disease. Thromb Res 2007;120:477-84.

[19] Cotter G, Shemesh E, Zehavi M, et al. Lack of aspirin effect: aspirin resistance or resistance to taking aspirin? Am Heart J 2004;147:293-300.

[20] Valles J, Santos MT, Aznar J, et al. Erythrocyte promotion of platelet reactivity decreases the effectiveness of aspirin as an antithrombotic therapeutic modality: the effect of low-dose aspirin is less than optimal in patients with vascular disease due to prothrombotic effects of erythrocytes on platelet reactivity. Circulation 1998;97:350-5.

[21] Michelson AD, Furman MI, Goldschmidt-Clermont P, et al. Platelet GP IIIa Pl(A) polymorphisms display different sensitivities to agonists. Circulation 2000;101:1013-8.

[22] Cipollone F, Rocca B, Patrono C. Ciclooxygenase-2 expression and inhibition in atherothrombosis. Arterioscler Thromb Vasc Biol 2004;24:246-55.
[23] Giusti B, Gori AM, Marcucci R, et al. Role of glycoprotein Ia gene polymorphisms in determining platelet function in myocardial infarction patients undergoing percutaneous coronary intervention on dual antiplatelet treatment. Atherosclerosis 2006 doi:10.16/j. atherosclerosis.2006.11.009.

[24] Mannini L, Marcucci R, Paniccia R, et al. Erythrocyte deformability and white blood cell count are associated with aspirin resistance in highrisk vascular patients. Clin Hemorheol Microcirc 2006;35:175-81.

[25] Pulcinelli FM, Pignatelli P, Celestini A, Riondino S, Gazzaniga PP, Violi F. Inhibition of platelet aggregation by aspirin progressively decreases in long-term treated patients. J Am Coll Cardiol 2004;43:979-84.

[26] Paniccia R, Antonucci E, Gori AM, et al. Comparison of different methods to evaluate the effect of aspirin on platelet function in high risk patients with ischemic heart disease on dual antiplatelet treatment. Am J Clin Pathol 2007;128:143-9.

[27] Michelson AD, Cattaneo M, Eikelboom JW, et al. Aspirin resistance: position paper of the Working Group on Aspirin Resistance. J Thromb Haemost 2005;3:1309-11. 